\title{
Creating Energy Field
}

\author{
Berov G Lyubomir* \\ Engineer, Independent Innovative Ideas Researcher, Bulgaria
}

*Corresponding author: Berov G Lyubomir, Engineer, Independent Innovative Ideas Researcher, Smolyan 4700, Bulgaria

\begin{abstract}
ARTICLE INFO
Received: 慧 June 14, 2019

Published: 幽 June 21, 2019

ABSTRACT

Dear reader, do you like the idea that everything around us is alive? And if we look at the world like that, whether it will become more understandable and more enjoyable for life, and we will not feel at times so lonely?
\end{abstract}

Citation: Berov G Lyubomir. Creating Energy Field. Biomed J Sci \& Tech Res 19(1)-2019. BJSTR. MS.ID.003245.
Keywords: Creating Energy Field; The Creation of Adam; Manually; Spiritual Side; Awe

\section{Editorial}

Dear reader, with this article I will try to clarify the process of creation according to my philosophical understanding. I will begin with Michelangelo's great mural painting "The Creation of Adam," which is in the Sistine Chapel. God bestows life to Adam by almost touching Adam's hand with his finger. According to the Bible, this is the moment when Adam becomes a living intelligent being, the most important quality he already possesses is his own creating energy field, which is a microscopic particle of God's creating energy field. In the article below, instead of creating energy field, I will only use the word Field. In my opinion the Field and the Soul are equivalent, and I will often replace them. And now for my philosophical understanding. At their core lies the assumption that every living thing that has been bestowed with a particle of the Field can in turn bestow particles from its own Field and thus bring to life some of its creations, which in turn can do the same. And this process is repeated indefinitely. Let's move on to more specific things that support this thesis First of all, I think that the process of creation has two sides - material, which is related to manipulating by hands on the material object - subject of the future creation, and spiritual, related to the spiritual influence of the Field on the object of creation. Here I have to note - it is very important to know that the smallest loss of the Field that is bestowed is in the direct work by hands. And more devices, machines, robots, etc. are used, the power of the bestowed Field is smaller so the vitality of the future creation is also smaller.

In support of this I bring facts from the production of the most expensive brands of cars: Bentley chief engineer Rolf Frach says, "We make $95 \%$ of the cars manually, so their value is justified."Bugatty -
Made with many hours of manual labor at the brand's factory located in Molsheim France, the car definitely deserves admiration. Many automakers would like to be in the place of one of the mechanics or specialists involved in the production process. The attention to the details is amazing, and this separates this machine from the many, made by robots and other devices, mass produced cars. Aston Martin: Although Aston Martin has been out of Ford's control for more than six years, its V8 and V12 engines are being made at the Blue Oval plant in Cologne. The production of aggregates takes place in separate production facilities with extensive use of manual labor. The participation of hands in the creation of works of art is crucial! We can now make any kind of sculpture with a 3D printer, but it will be soulless creations that, as we will seen below, will not attract anyone. Now, more specifically about the spiritual side of the creation and the Field. As I have already mentioned, according to my human understanding, the creating energy field is one of the most important energy fields for the existence of the material world. Here's how I see it effect in the human world: some people /too few, unfortunately / radiated at certain moments powerful / for human scale and understanding / creating energy. And then, in our human world, wonderful creations are realized in the form of paintings, sculptures, music, poetry, philosophical concepts, buildings, etc. Most of the other people, who come in contact with these creations, capture and realize this energy and this brings them immeasurable and generally incomprehensible joy. But the action of the Field is inherent in every person, and its creation can be something quite ordinary, which is necessary for its everyday existence.

But whatever it is, I am confident that apart from the material, it also contains part of creating energy field of its creatior and, to 
a certain extent, is a living being that once created already exists on its own. Let this be just a hypothesis for now. Let's risk and accept it as truth and move on. The creation is alive! As such, it experiences its childhood, maturity and eventually its life ends. The most elementary example of such a creation is a tasty dish prepared by your mother. Here is another example: It is known from the story that the great painter Vincent van Gogh has painted hundreds of magnificent paintings that apparently possessed a very, very creating energy field as part of Van Gogh's vast creating energy field. While he was alive, however, his paintings weren't liked and he managed to sell only one - the paintings were living their childhood. After his death there was a rapid change in the situation and now his paintings are one of the most valuable - they are in their maturity. Dear reader, isn't this like this story of the ugly duckling and the magnificent swan?! But to continue. Man-made and already existing independently creations, especially those that are bestowed by their creators with more of the creating energy field, can interact among themselves and obviously with their creator - the man. This contact is now inexplicable because our five senses cannot do it, but as I have said above, it is enough to stand before some great work of art and more or less each of us senses it. Besides the joy at the time of the meeting, a long time after, one feels an increase in his own creative abilities. More simply, this process can be considered as such: the creator separates part of his Field and with this part breathes life into his creation. It can now, like a living being, return in a similar way the creating energy field to its viewers.

Now let's try to trace what happens to us when we visit, say, a world-famous cathedral. It has many great works of art and architecture, as well as simple constructive performances, all of which are connected by the common spirit of the cathedral. And this common spirit, or to call it a soul, is a sum of the parts of the Fields of many talented individuals, as well as the many ordinary workers who built the cathedral. The contribution of each of them to the soul of the cathedral is different, but everyone has a contribution. So we enter the cathedral. Around us there are many visitors. At first they distract us, but after a while we feel a special atmosphere around us, and gradually, even without looking at a particular performance, we have a sense of awe. Let's stop here. This is the spirit of the cathedral - she is alive and is trying to contact us. Now, to expand the concept of "human creations." In fact, these are all other collective human works. Each of them, even if not created by ingenious people, in my opinion has a Field that is a sum of particles from the individual Fields of every ordinary person involved in its creation. It is, in its own way, alive and, in general, it is born, lives and dies or gets reborn. How does this work? If the issue is about large collective human creations such as cities, for example, human history is categorical - they are being refreshed mainly through huge fires. Here are specific examples: From year 406 to year 1204 Constantinople burned to the ground five times. One of the most remarkable cities in our history has been rebuilt every time at the speed of anthill. The newly built city is always more beautiful and more comfortable for life.

In the interval between year 1212 and year 1666, London has burned six times and was ironically called a matchbox. The disaster in 1212 took over 3,000 human lives. The fire in 1666 was known to devastate forever the so-called dirty ghettos created by the plague epidemics that plagued the city only a year earlier. In this way, the city was cleared of miasms and largely sterilized after the epidemic. In fact, the fire has served the city and the whole country, but to this day too many people doubt its being unpremeditated. The Chicago Fire, along with the London Fire in year 1666, is the most famous fire in history. In October 1871 it burned over 17,000 buildings and left 90,000 homeless. This fire, however, puts a better foundation for the reborn Chicago. The city that rises from the ashes is much more beautiful and comfortable. Dear reader, I look at these examples because these fires started spontaneously for unexplained unsubstantiated reasons. These are not fires caused by military action. The cities mentioned above resemble living sick creatures that, after a severe crisis, recover and come back to life. The construction of the new cities, however, is always the result of the collective efforts of many people who have been releasing particles from their Fields to provide a rich and powerful soul to the new creation. Dear reader, do you like the idea that everything around us is alive? And if we look at the world like that, whether it will become more understandable and more enjoyable for life, and we will not feel at times so lonely?

\section{ISSN: 2574-1241}

DOI: 10.26717/BJSTR.2019.19.003245

Berov G Lyubomir. Biomed J Sci \& Tech Res

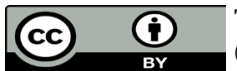

This work is licensed under Creative Commons Attribution 4.0 License

Submission Link: https://biomedres.us/submit-manuscript.php

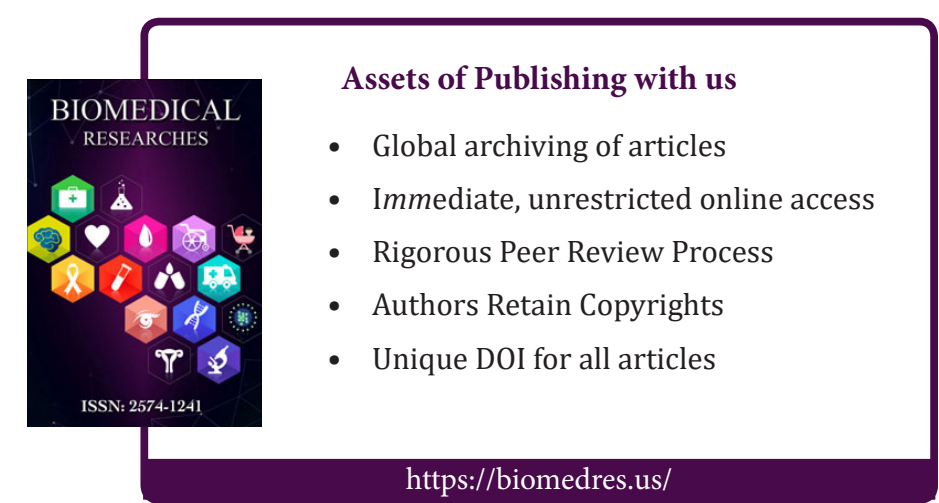

